\title{
Cultural and Morphological Characteristics of Different Xanthomonas axonopodis pv. punicae Isolates on Nutrient Agar Media
}

\author{
A.G. Patil*, C.V. Ambadkar, K.M. Kanase and V.S. Kashid
}

Department of Plant Pathology, College of Agriculture, Latur Vasantrao Naik Marathwada

Krishi Vidyapeeth, Parbhani, Maharashtra, India

*Corresponding author

\section{A B S T R A C T}

\begin{tabular}{|l|}
\hline K e y w or d s \\
Bacterial blight, \\
Pomegranate, \\
Morphological, \\
Cultural, \\
Physiological, \\
Temperature, salt \\
sensitivity, pH.
\end{tabular}

Keywords

Bacterial blight,

Pomegranate,

ogical

Temperature, sal

sensitivity, $\mathrm{pH}$

\section{Introduction}

India is the leading pomegranate producer which contributes nearly 50 per cent of the world's production. Cultivation of high yielding varieties of pomegranate with intensive care and management in the recent past under irrigated condition with early stage exploitation of plants has lead to certain severe pest and disease problems. Among the major diseases leaf spot, fruit spot and wilt results in reduction of pomegranate fruit yield and put the growers in to hardship. Pomegranate grows very well on the moderately alkaline soils as well as slightly acidic soils. It is common to the tropics, subtropics and sub-temperate regions and is well adapted to areas with hot and dry summers. For the first time in India, leaf spot of pomegranate was reported Hingorani and Mehta (1952). Later on during 1959, Hingorani and Singh took a thorough investigation on the disease and causal organism and designated the pathogen as Xanthomonas punicae. Chand and Kishun (1991) had isolated the causal organism of bacterial blight of pomegranate and based on its pathological, cultural, biochemical and physiological features, identified as a Xanthomonas campestris pv. punicae. Further in year 1995, Vauterin et al., (1995) had renamed this causal organism as Xanthomonas 
axonopodis pv. punicae keeping in view of activity of the presence or absence of metabolic activity on different carbon substrates.

\section{Materials and Methods}

\section{Morphological characters}

The morphological characters such as shape, gram reaction and pigmentation characters were studied as described by Society of American Bacteriologists, Bradbury (1970) and Schaad and Stall (1992).

\section{Cultural character}

Different isolates of Xanthomonas axonopodis pv. punicae grown on nutrient agar media and stored at $28 \pm 2{ }^{\circ} \mathrm{C}$ temperature. The observations were recorded after 72 hours. The colour of colony was recorded following Ridway colour standard and colour nomenclature (Ridway, 1912).

Effect of physical factors on the growth and multiplication of Xanthomonas axonopodis pv. punicae

\section{Temperature requirement}

An experiment was conducted to know the optimum temperature required for the growth of Xanthomonas axonopodis pv. punicae isolates causing bacterial blight of pomegranate in different agroclimatic zones. The bacterial cultures were multiplied separately in nutrient broth. The cultures were prepared by inoculating a loopful of bacterial cultures from stock culture to $100 \mathrm{ml}$ nutrient broth contained in $250 \mathrm{ml}$ conical flask and incubated for 72 hours at $28^{\circ} \mathrm{C}$. Fifty microlitre of the bacterial cultures diluted to a concentration of $5 \times 10^{5} \mathrm{cfu} / \mathrm{ml}$ was poured on to the surface of nutrient agar medium taken in sterilized Petri dishes. The bacterial suspension was uniformly spread with the help of a sterilized glass spreader so as to obtain well distributed bacterial colonies. The inoculated plates were incubated at different temperatures viz., 28 and $37^{\circ} \mathrm{C}$ for $48,72,96$ and 120 hours. Observations were recorded on the number of colonies appearing after the incubation period at each temperature.

\section{$\mathrm{pH}$ requirement}

The effect of hydrogen ion concentration on the growth of the bacterial isolates was studied by adjusting the $\mathrm{pH}$ of the nutrient agar. The $\mathrm{pH}$ was adjusted to 5, 5.5, 6, 6.5 and 7 using appropriate buffers.

A loopful of 72 hours old bacterial culture was serially diluted to $9 \mathrm{ml}$ sterilized water blanks. One $\mathrm{ml}$ of $10^{-5}$ dilution was plated separately on to the surface of the medium having varied $\mathrm{pH}$ levels. The suspension was spread uniformly over the medium with the help of sterilized spreader. Inoculated plates were incubated at $28^{\circ} \mathrm{C}$ temperature for 72 hours. After the incubation period, observations were recorded for the development of colonies on the media having different $\mathrm{pH}$. Colonies were counted and recorded. Data was analyzed statistically.

\section{Salt concentration}

The effect of salt concentration on the growth of bacterial isolates was studied by adjusting the salt concentration of Nutrient Agar. Salt sensitivity of different level such as 1\%, 2\% and $3 \%$ salt concentration was tested.

A loopful of 72 hours old bacterial culture was serially diluted to $9 \mathrm{ml}$ sterilized water blank. One $\mathrm{ml}$ of dilution was plated separately on the surface of medium having varied salt concentration. The suspension was spread uniformly over the medium with the help of sterilized spreader. Inoculated plates 
were incubated at $28^{\circ} \mathrm{C}$ temperature for 72 hours. After the incubation period, observations were recorded for the development of colonies on the media having different salt concentration. Colonies were counted and recorded.

\section{Results and Discussion}

\section{Cultural and morphological characteristics of different Xap isolates on nutrient agar media}

Cultural and morphological characters of different Xap isolates were studied on nutrient agar media (Table 1). The data revealed that the isolates differed in respect of size of colony as the isolates Xap-1 and Xap-4 developed medium to large bacterial colonies. The isolates Xap-1 and Xap-3 developed small to medium sized bacterial colonies, Xap-5 produced small bacterial colonies. The isolates of Xanthomonas axonopodis pv. punicae also differed greatly in shape of colony as the Xap-1 and Xap-3 produced small circular colonies, Xap-2 and Xap-4 produced circular to irregular bacterial colonies Xap-5 produced circular bacterial colonies.

The isolates also differed in respect to colour of bacterial colonies. Xap-1 and Xap-4 showed yellowish bacterial colonies, Xap-2 and Zap-5 showed light yellow coloured colonies, Xap-3 showed yellow coloured bacterial colonies. Five isolates showed significant difference in their appearance. Xap-3 and Xap-4 showed highly raised, glistering appearance, Xap-1, Xap-2 and Xap5 showed slightly raised, glistering appearance. All the isolates showed single rod and convex elevation and slightly mucoid to highly mucoid texture. Results on morphological characters of $X$. axonopodis pv. punicae in present investigation are similar with the results of earlier workers Hingorani and Singh (1959), Kanwar (1976) and Jalaraddi (2006). Jalaraddi (2006) reported that the bacteria isolated from infected parts of pomegranate was found to be aerobic, Gram negative, capsulated, non-spore forming and monotrichously flagellated, whereas, Manjula (2002) observed that the repeated isolations made from the infected parts of pomegranate plant yielded yellow, mucoid, glistening, slimy, convex and odourless colonies on Nutrient Agar (Table 2).

\section{Growth rate of different Xap isolates at $28^{0} \mathrm{C}$ and $37^{\circ} \mathrm{C}$}

The effect of varied temperature levels on the growth of Xap was studied and data so obtained is presented in Table 3. All the Xap isolates were tested at temperature $28^{\circ} \mathrm{C}$ and $37{ }^{\circ} \mathrm{C}$ on NA agar medium. The data clearly indicated that the temperature of $28^{\circ} \mathrm{C}$ was found optimum for the growth of the pathogen as significantly maximum number of colonies was observed at this temperature.

All isolates grew well at $28^{0} \mathrm{C}$ but no growth was observed at temperature of $37^{\circ} \mathrm{C}$. Growth of Xap started $72 \mathrm{hrs}$ after incubation. Maximum growth was observed after $120 \mathrm{hrs}$ of incubation at $28^{\circ} \mathrm{C}$ but no growth was observed after $48 \mathrm{hrs}$ of incubation. At $37^{\circ} \mathrm{C}$ no growth was observed upto $120 \mathrm{hrs}$.

Similar work on temperature requirement was carried out by Hingorani and Mehta (1952).They found that the pomegranate bacterium grows well at a cordial temperature of $30^{\circ} \mathrm{C}$ and can tolerate a minimum and maximum temperature of 5 and $40^{\circ} \mathrm{C}$, respectively. Gour et al., (2000) also got the similar results while working with $X$. axonopodis pv. vignicola, the causal agent of leaf blight of cowpea. They have recorded the maximum growth of the pathogen at a temperature level of $30^{\circ} \mathrm{C}$, whereas, Manjula (2002) recorded the highest number of colonies of Xap at a temperature of $27^{\circ} \mathrm{C}$. 
Table.1 Isolates used for cultural, morphological and physiological test

\begin{tabular}{|l|l|l|l|l|l|}
\hline $\begin{array}{c}\text { Sr. } \\
\text { No. }\end{array}$ & $\begin{array}{c}\text { Name of } \\
\text { isolate }\end{array}$ & $\begin{array}{c}\text { Place of } \\
\text { collection }\end{array}$ & District & Pathogen identified & $\begin{array}{c}\text { Affected plant } \\
\text { part }\end{array}$ \\
\hline 1 & Xap-1 & Naigaon & Osmanabad & $\begin{array}{l}\text { Xanthomonas } \\
\text { axonopodis } \text { pv. punicae }\end{array}$ & Leaf/Stem/Fruits \\
\hline 2 & Xap-2 & Murud & Latur & $\begin{array}{l}\text { Xanthomonas } \\
\text { axonopodis pv. punicae }\end{array}$ & Leaf/Fruits \\
\hline 3 & Xap-3 & Washi & Osmanabad & $\begin{array}{l}\text { Xanthomonas } \\
\text { axonopodis } \text { pv. punicae }\end{array}$ & Leaf \\
\hline 4 & Xap-4 & Ashta & Latur & $\begin{array}{l}\text { Xanthomonas } \\
\text { axonopodis pv. Punicae }\end{array}$ & Leaf/Fruits \\
\hline 5 & Xap-5 & Killari & Latur & $\begin{array}{l}\text { Xanthomonas } \\
\text { axonopodis } \text { pv. punicae }\end{array}$ & Leaf/Fruits \\
\hline
\end{tabular}

Table.2 Cultural and morphological characteristics of different Xap isolates on nutrient agar media

\begin{tabular}{|c|c|c|c|c|c|}
\hline $\begin{array}{c}\text { Colony } \\
\text { characters }\end{array}$ & Xap-1 & Xap-2 & Xap-3 & Xap-4 & Xap-5 \\
\hline Colour & Yellowish & Light yellow & Yellow & Yellowish & Light yellow \\
\hline Size of colony & $\begin{array}{c}\text { Small to } \\
\text { medium }\end{array}$ & $\begin{array}{c}\text { Medium to } \\
\text { large }\end{array}$ & $\begin{array}{c}\text { Small to } \\
\text { medium }\end{array}$ & $\begin{array}{c}\text { Medium to } \\
\text { large }\end{array}$ & Small \\
\hline Shape of colony & $\begin{array}{c}\text { Small Circular } \\
\text { colonies }\end{array}$ & $\begin{array}{c}\text { Circular to } \\
\text { irregular }\end{array}$ & $\begin{array}{c}\text { Small Circular } \\
\text { colonies }\end{array}$ & $\begin{array}{c}\text { Circular to } \\
\text { irregular }\end{array}$ & Circular \\
\hline Cell shape & Single rod & Single rod & Single rod & Single rod & Single rod \\
\hline Appearance & $\begin{array}{c}\text { Slightly raised, } \\
\text { glistening }\end{array}$ & $\begin{array}{c}\text { Slightly raised, } \\
\text { glistening }\end{array}$ & $\begin{array}{c}\text { Highly raised, } \\
\text { glistening }\end{array}$ & $\begin{array}{c}\text { Highly raised, } \\
\text { glistening }\end{array}$ & $\begin{array}{c}\text { Slightly raised, } \\
\text { glistening }\end{array}$ \\
\hline Elevation & Convex & Convex & Convex & Convex & Convex \\
\hline Margin & Entire margin & Entire margin & Entire margin & Entire margin & Entire margin \\
\hline Texture & $\begin{array}{c}\text { Slightly } \\
\text { mucoid }\end{array}$ & Highly mucoid & $\begin{array}{c}\text { Slightly } \\
\text { mucoid }\end{array}$ & $\begin{array}{c}\text { Highly } \\
\text { mucoid }\end{array}$ & $\begin{array}{c}\text { Slightly } \\
\text { mucoid }\end{array}$ \\
\hline
\end{tabular}

Table.3 Growth rate of different Xap isolates at $28^{0} \mathrm{C}$ and $37^{\circ} \mathrm{C}$

\begin{tabular}{|l|l|c|c|c|c|c|c|c|c|}
\hline \multirow{2}{*}{$\begin{array}{l}\text { Sr. } \\
\text { No. }\end{array}$} & \multirow{2}{*}{ Isolates } & \multicolumn{9}{|c|}{ Growth rate } \\
\cline { 3 - 10 } & & \multicolumn{9}{|c|}{$\mathbf{2 8}^{\mathbf{0}} \mathbf{C}$} \\
\cline { 3 - 10 } & & $\mathbf{4 8} \mathbf{~ h r s}$ & $\begin{array}{c}\mathbf{7 2} \\
\text { hrs }\end{array}$ & $\begin{array}{c}\mathbf{9 6} \\
\text { hrs }\end{array}$ & $\begin{array}{c}\mathbf{1 2 0} \\
\text { hrs }\end{array}$ & $\mathbf{4 8}$ hrs & $\begin{array}{c}\mathbf{7 2} \\
\text { hrs }\end{array}$ & $\begin{array}{c}\mathbf{9 6} \\
\text { hrs }\end{array}$ & $\begin{array}{c}\mathbf{1 2 0} \\
\text { hrs }\end{array}$ \\
\hline 1 & Xap-1 & - & + & ++ & +++ & - & - & - & - \\
\hline 2 & Xap-2 & + & ++ & ++ & +++ & - & - & - & - \\
\hline 3 & Xap-3 & + & ++ & ++ & +++ & - & - & - & - \\
\hline 4 & Xap-4 & - & + & ++ & +++ & - & - & - & - \\
\hline 5 & Xap-5 & - & + & ++ & +++ & - & - & - & - \\
\hline
\end{tabular}

Colony growth: '-’: no growth, ‘+': less growth, ‘++': moderate growth, ‘+++': maximum growth. 
Table.4 Growth rate of different Xap isolates at different $\mathrm{pH}$

\begin{tabular}{|c|c|c|c|c|c|c|}
\hline \multirow{2}{*}{ Sr. no. } & \multirow{2}{*}{ Isolates } & \multicolumn{5}{|c|}{ Growth rate at pH } \\
\cline { 3 - 7 } & & $\mathbf{5 . 0}$ & $\mathbf{5 . 5}$ & $\mathbf{6 . 0}$ & $\mathbf{6 . 5}$ & $\mathbf{7 . 0}$ \\
\hline 1 & Xap-1 & - & - & + & +++ & +++ \\
\hline 2 & Xap-2 & - & + & ++ & +++ & +++ \\
\hline 3 & Xap-3 & - & + & ++ & +++ & +++ \\
\hline 4 & Xap-4 & - & - & ++ & +++ & +++ \\
\hline 5 & Xap-5 & - & + & ++ & +++ & +++ \\
\hline
\end{tabular}

Colony growth: - '-' no growth, '+' less growth, '++' moderate growth, '+++' maximum growth.

Table.5 Salt sensitivity of different Xap isolates at different level

\begin{tabular}{|c|c|c|c|c|}
\hline \multirow{2}{*}{$\begin{array}{c}\text { Sr. } \\
\text { no }\end{array}$} & \multirow{2}{*}{ Isolates } & \multicolumn{3}{|c|}{ Growth rate at salt concentration } \\
\cline { 3 - 5 } & & $1 \%$ & $2 \%$ & $3 \%$ \\
\hline 1 & Xap-1 & ++ & - & - \\
\hline 2 & Xap-2 & ++ & - & - \\
\hline 3 & Xap-3 & ++ & - & - \\
\hline 4 & Xap-4 & ++ & - & - \\
\hline 5 & Xap-5 & +++ & - & - \\
\hline
\end{tabular}

Colony growth: - '-' no growth, '+' less growth, '++' moderate growth, '+++' maximum growth.

Growth rate of different Xap isolates at different pH

The effect of varied $\mathrm{pH}$ levels on the growth of Xap was observed and the data so obtained is presented in Table 4. From the data it was clear that the maximum growth of Xap isolates was observed at $\mathrm{pH} 6.5$ and 7 , whereas, moderate growth of Xap-2, Xap-3, Xap-4, Xap-5 isolates was observe at $\mathrm{pH} 6.0$ except Xap-1 which showed less growth at $\mathrm{pH}$ 6.0. Isolate Xap-2, Xap-3 and Xap-5 showed less growth at $\mathrm{pH}$ level 5.5, whereas, Xap-1 and Xap-4 showed no growth at $\mathrm{pH}$ 5.5. All the isolates failed to grow at $\mathrm{pH}$ 5.0.

The results of the present investigation correlates with results of earlier worker, where, Gour et al., (2000) got the similar results while working with $X$. axonopodis pv. vignicola, the causal agent of leaf blight of cowpea. They have recorded the maximum growth of the pathogen at a $\mathrm{pH}$ of 7.0. Growth (number of colonies) declined considerably at $\mathrm{pH}$ values higher and lower than 7.0 being minimum at a $\mathrm{pH}$ of 5.0. Manjula (2002) recorded the highest number of colonies of Xap at $\mathrm{pH}$ of 7.2., whereas, Mondal and Kumar (2011) reported the growth of Xap at $\mathrm{pH} 6$ and above and absence of growth at $\mathrm{pH}$ below 5 .

\section{Salt sensitivity of different Xap isolates at different level}

The effect of varied salt concentrations on the growth of Xap was observed and the data so obtained is presented in Table 5. Five isolates were tested for their growth at different salt concentration level. All Xap isolates showed maximum growth at 1 per cent salt concentration, whereas, all these isolates failed to grow at 2 per cent and 3 per cent salt concentration. The results of the present study are in confirmation with the results of Mondal 
and Kumar (2011), where they found that Xap tolerates upto $1 \% \mathrm{NaCl}$ concentration, beyond that no growth of the pathogen was noticed. Basamma (2013) tested 18 isolates of Xap. Growth of all isolates at zero per cent $\mathrm{NaCl}$ concentration was significantly superior to (mean OD value 0.354 ) other treatments which was followed by one per cent (mean OD value 0.223 ) while growth at 3 and 4 per cent was zero. Among the isolates, Xap2 and Xap10 produced maximum OD value 0.231 and 0.230 which were on par with each other and was significantly superior to all other isolates followed by Xap14 (0.206). In general zero per cent $\mathrm{NaCl}$ concentration was found to be preferred by all isolates.

\section{References}

Basamma (2013). Molecular phylogenetic analysis of Xanthomonas axonopodis pv. punicae isolates and bio-prospecting of selected botanicals and bio-agents against bacterial blight of pomegranate. Ph.D. Thesis, submitted to Univ. of Agric. Sci. Dharwad.

Bradbury, J. F. (1970). Isolation and preliminary study of bacteria from plants. Rev. Pl. Pathol., 49: 213-218.

Chand, R. and Kishun, R. (1991). Studies of bacterial blight (Xanthomonas campestris pv. punicae) of pomegranate. Indian Phytopath. 44 (3): 370-372.Hingorani, M. K. and Mehta, P. P. (1952). Bacterial leaf spot of pomegranate. Indian Phytopath. 5: 55-56.

Gour, H. N., Ashiya, J., Mali, B. L. and Ranjan Nath (2000). Influence of temperature and $\mathrm{pH}$ on the growth and toxin production by Xanthomonas axonopodis $p v$. vignicola inciting leaf blight of cowpea. J. Mycol.
Pl. Path. 30(3) : 389-392.

Hingorani, M. K. and Singh, N. J. (1959). Xanthomonas sp. on Punica granatum $\mathrm{L}$. Indian J. Agric. Sci., 29: 45-48.

Jalaraddi, J. N. (2006). Biological control of Bacterial blight of pomegranate caused by Xanthomonas axonopodis pv. punicae. $M$. Sc. (Agri.) Thesis, submitted to Univ. of Agric. Sci., Bangalore. pp: 126.

Kanwar, Z. S. (1976). A note on disease of pomegranate (Punica granatum) Hariyana. J. Horti. Sci. 5: 171-180

Manjula, C. P. (2002). Studies on bacterial blight of pomegranate (Punica granatum L.) caused by Xanthomonas axonopodis pv. punicae. M. Sc. (Agri.) Thesis, submitted to Univ. of Agri. Sci., Bangalore.pp: 98.

Mondal, K. K. and A. Kumar (2011). Phenotype based identification of Xap: Practical Manual on Advances in Phenomics, Genomics and Diagnostics of Xap Causing Bacterial Blight of Pomegranate. pp: 5-11.

Ridway, R. (1912). Color standards and color nomenclature. Curator of the Division of Birds, United States National Museum. 144-145.

Schaad, N. W. (1992). Laboratory guide for the identification of plant pathogenic bacteria. $2^{\text {nd }}$ ed. American Phytopath. Soc. pp: 138.

Schaad, N. W. and R. E. Stall (1988). Xanthomonas. In: Laboratory guide for identification of plant pathogenic Bacteria, Edn. II, pp: 81-94.

Vauterin, L., Haste, B., Kersters, K. and J. Swings (1995). Reclassification of Xanthomonas. Int. J. Syst. Bacterial. 45: 475-489.

\section{How to cite this article:}

Patil, A.G., C.V. Ambadkar, K.M. Kanase and Kashid, V.S. 2017. Cultural and Morphological Characteristics of Different Xanthomonas axonopodis pv. punicae Isolates on Nutrient Agar Media. Int.J.Curr.Microbiol.App.Sci. 6(11): 1678-1683. doi: https://doi.org/10.20546/ijcmas.2017.611.201 